\title{
Detection of dengue virus serotype 3 by reverse transcription- polymerase chain reaction in Aedes aegypti (Diptera, Culicidae) captured in Manaus, Amazonas
}

\author{
Valéria CS Pinheiro/*/+ , Wanderli P Tadei*, Patrícia MSS Barros**, \\ Pedro FC Vasconcelos**, Ana Cecília R Cruz**
}

\begin{abstract}
Laboratório de Malária e Dengue, Instituto Nacional de Pesquisas da Amazônia, Av. André Araújo 2936, 69083-000 Manaus, AM, Brasil *Universidade Estadual do Maranhão, Caxias, MA, Brasil **Departamento de Arbovirologia e Febres Hemorrágicas Instituto Evandro Chagas, Belém, PA, Brasil

The detection of dengue virus serotypes from Aedes aegypti in Manaus, state of Amazonas was carried out using the reverse transcription-polymerase chain reaction technique. Fourteen pools out 82 (17.1\%) were positive for DENV3, providing a minimal infection rate of $2.1 \%$ of all analyzed infected female specimens of three different areas of the city.
\end{abstract}

Key words: Aedes aegypti - reverse transcription-polymerase chain reaction - dengue serotypes - virus isolation - Manaus - Brazil

The occurrence of dengue cases including dengue hemorrhagic fever (DHF) in Brazil has increased since 1990s. It is the viral disease with the largest number of cases. In the first half of 2003, 259,800 cases were recorded in the country (MS 2003).

Despite the strong control measures program adopted to control the distribution of the mosquito vector of dengue in Brazil, the Aedes aegypti indexes remain increased and has not been possible to avoid dengue widespread (Braga 2004). Presently three dengue serotypes (DENV1, DENV2, and DENV3) are circulating in 25 of the 27 Brazilian states (MS 2005). The sequential introduction of the three serotypes and the spread of DENV3 since 2001, favored the occurrence of outbreaks. DENV3 has been associated to more severe cases of disease happened in Brazil and is the serotype responsible for mostly occurrence of DHF in the last epidemics (Miagostovich et al. 2002, Figueiredo 2003).

The state of Amazonas was one of the last states in Brazil to become infested by Ae. aegypti (Figueiredo et al. 2002). The wide dispersal of this species in the city of Manaus, state of Amazonas, took place in 1996, and two years later, an epidemic with 13,873 cases were reported in Amazonas State capital. In 1998 were detected serotypes DENV1 and DENV2 (Figueiredo et al. 2002). During 2002, the DENV3 was isolated for the first time in Manaus from two patients (Araújo et al. 2003). DHF cases were recorded in 2001 (55) and 2003 (59) (Sinan 2004).

In the Amazon Region, environmental and social factors, such as high temperature and humidity during the

Financial support: CNPq-PNOPG/INPA-MCT/Susam ${ }^{+}$Corresponding author. E-mail: valeria@ cesc.uema.br Received 19 April 2005

Accepted 14 December 2005 year, the extended rainy season, and pour basic infrastructure, provides ideal conditions for the proliferation of dengue vectors reproduction (Vasconcelos et al.1999, Pinheiro \& Tadei 2002).

The constant presence of Ae. aegypti throughout the city, as well as the co-circulation of three viral serotypes, represents risk for the occurrence of severe dengue epidemics. This situation shows the need of establishing efficient laboratory techniques for detecting viral serotypes, providing a rapid diagnosis and facilitating proper control measures in order to prevent or reduce the epidemic impacts.

Many works have been developed using the reverse transcription-polymerase chain reaction (RT-PCR) since the 1990s to determine infection rates in humans (Lanciotti et al. 1992, Chungue et al. 1993, Harris et al. 1998, Kouri et al. 1998, Joshi et al. 2002). The use of RT-PCR to detect dengue viruses on vector tissues has allowed estimating vector transmission ability by the analysis of the infection on them. It is also possible to detect the serotype circulating within an area, which is a crucial information for the surveillance of dengue epidemics.

Studies targeted to detect dengue virus serotypes in mosquitoes using viral isolation or RT-PCR procedures in Brazil have been published elsewhere (Nogueira et al. 1988, Vasconcelos et al. 1998, Lourenço-de-Oliveira et al. 2002, Castro et al. 2004). Some of them were restrict to epidemiological data analysis when the epidemic has already established itself. The knowledge of the dengue serotypes circulating within a locality is also fundamental for public health, since it is known that some virus strains can cause more severe clinical manifestations, which are commonly observed in places where co-circulate two or more serotypes (Halstead 1980, Vaughn et al. 2000, Messer et al. 2003).

The aim of this study was to investigate the presence of dengue serotypes circulating in the city of Manaus in 2003, using the RT-PCR technique from adult Ae. aegypti captured in several districts reporting high indexes of fe- 
brile illness clinically diagnosed as dengue fever. Immature stages of Ae. aegypti were also used for studies about transovarial transmission.

\section{MATERIALS AND METHODS}

Specimen collection - Samples comprised of adult mosquitoes and immature forms of Ae. aegypti collected from households where residents were suspected of dengue fever in different localities of Manaus (Fig. 1). Adult male and female mosquitoes and immature forms (larvae and pupae) were collected to investigate the possibility of dengue virus transovarial transmission. Resting winged-mosquitoes were captured with mechanical aspirator furnitures and in the upper parts of the houses. Where there might have been a chance of finding infected mosquitoes. Following collections, mosquitoes were anesthetized on ice, identified, pooled by gender, date and place of capture, and stored at $-70^{\circ} \mathrm{C}$. Pools ranged from one to 34 mosquitoes.

The immature forms were collected from containers by using plastic pipettes, identified and washed twice in distilled water to remove impurities (Klin \& Klin 1983) and were grouped as described before, but the lots ranged from 4 to 49 specimens, which were treated as described by Reynes (1995). Then, lots were stored at $-70^{\circ} \mathrm{C}$ or immediately used for RNA extractions, which were carried out using the Trizol LS Reagent (Invitrogen, San Diego, US) method following the manufacturer's protocol.

Reverse transcriptase and semi-nested reactions were performed, by using specific primers targeted to the PrM/ $\mathrm{M}$ genomic region of all dengue virus serotypes as described by Lanciotti et al. (1992).

Viral isolation and characterization - Suspensions of 1:10 prepared in PBS solution from the adult mosquito and immature form pools were inoculated on C6/36 cells culture grown in a Leibowitz medium (L-15, Invitrogen,
San Diego, US). After 10 days each lot was submitted to indirect immunofluorescence assays (IFA) using monoclonal antibodies against the four dengue virus serotypes as previously described by Gubler et al. (1984). Cultures of uninfected cells were used as negative controls.

Nucleotide sequencing - The PCR products were obtained for sequences of the $\mathrm{E}$ gene region (viral envelope), utilizing specific primers P992 (sense) and CP2550 (nonsense) (Lanciotti et al. 1994), and reverse transcriptase and high fidelity polymerase (PlatinumTaQ and Superscript II - Invitrogen, San Diego, US) enzymes were used as described by the manufacturer's. Then, they were purified by the Qiagen purification kit (Chatsworth-US), and sequenced in an ABI Prism 377 automatic sequencer using the Big Dye Terminator 3.0 kit (California, US) and specific primers for determining the nucleotide sequence (forward-P1685 and reverse-CP2550 Invritogen, São Paulo, Brazil). Sequences were assembled with the aid of a SeqMan software in order to assemble the counting and consensus sequence; alignment were obtained using the Clustal W method of the Megalign software (DNASTAR, Laser gene program package version 4.05) with sequences already recorded in the GenBank. A Molecular Evolutionary Genetics Analysis - MEGA, 2.1 - 2001 version software, that utilizes the neighbor-joining method using DNA distance relationship was used to prepare a dendogram of reference sequences previously described and sequences obtained in this study.

\section{RESULTS}

Between February and June 2003, during the rainfall season and elevate incidence of dengue in Manaus, a total 1816 specimens, being $674(31.1 \%)$ adult mosquitoes and 1,142 (68.9\%) immature forms, were collected from 35 different sites in the city. Table shows the amount of specimens captured at each site.
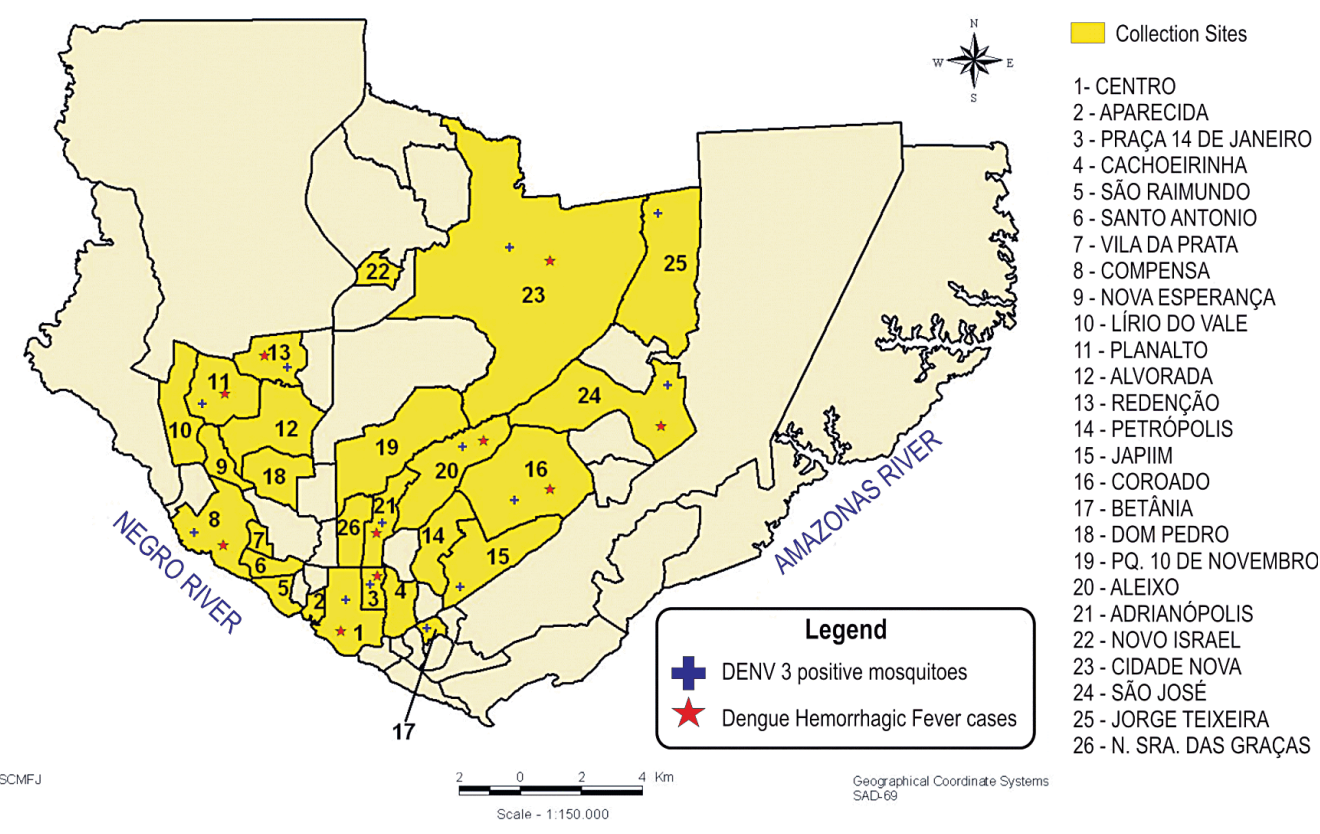

Fig. 1: map of Manaus showing the Aedes aegypti collection sites. 
From a total of 82 pools of Ae. aegypti adults RT-PCRanalyzed, $14(17.1 \%)$ were positive to DENV3, all of them composed of adult females (Table). Positive samples submitted to $2 \%$ agarose gel electrophoresis are shown on Fig. 2. All 59 pools of males and immatures forms were negative. Seven RT-PCR positive pools were inoculated in C6/36 cells, and DENV3 was isolated from two of them. Only the strain AR671089 positive to RT-PCR and viral isolation was sequencing. A 746 base sequence spanning the partial (E) envelope protein gene was sequenced to a 1458 base pairs product obtained by RT-PCR. Comparative analysis between the strains AR671089, AM2394 (access number AY632355) DENV3 isolate from a patient with DF and 13 DENV3 from GENBANK, representative of the main genotypes, showed that nucleic acid sequence similarity ranged from 85 to $95 \%$.

The phylogenetic analyses of this strain showed that it is grouped in the genotype III, which has been represented by viruses of the Southeast Asia within DENV3 serotype (Fig. 3).

\section{DISCUSSION}

The RT-PCR technique for detecting dengue virus in mosquito tissues has been performed in several regions of the world since the 1990s (Chungue et al. 1993, Chow et al. 1998, Harris et al. 1998, Romero-Vivas et al. 2000, Kow et al. 2001, Chung \& Pang 2002, Urdaneta et al. 2005). Mostly of these studies were conducted in Asia, where the four serotypes occur and the incidence of DHF/DSS is very high. The purpose of the study was to measure the viral infection rate in the vector population, as well as to maintain an active surveillance for early detection of a new serotype into areas where other serotypes are already been circulating.

In Brazil, the use of RT-PCR for monitoring of circulat-

TABLE

Number of Aedes aegypti adults and immature forms captured in Manaus by district and positive reverse transcriptionpolymerase chain mosquito lots from February to May 2003

\begin{tabular}{|c|c|c|c|c|}
\hline \multirow{2}{*}{ Localities } & \multirow{2}{*}{$\begin{array}{c}\text { No. of species } \\
\text { immature }\end{array}$} & \multicolumn{2}{|c|}{ Adults } & \multirow{2}{*}{$\begin{array}{l}\text { No. mosq. } \\
\text { /pool o }\end{array}$} \\
\hline & & $\mathrm{F}($ () & $M\left(o^{*}\right)$ & \\
\hline 1. Centro & 167 & 58 & 47 & $\begin{array}{l}31 \\
27\end{array}$ \\
\hline 2. Aparecida & - & 2 & 1 & \\
\hline 3. Praça 14 de Janeiro & 141 & 25 & 18 & 23 \\
\hline 4. Cachoeirinha & 57 & 13 & 18 & \\
\hline 5. São Raimundo & - & 3 & - & \\
\hline 6. Santo Antônio & - & 1 & - & \\
\hline 7. Vila da Prata & - & 5 & 4 & \\
\hline 8. Compensa I & - & 7 & 21 & 5 \\
\hline 8 A Compensa II & 7 & 4 & 4 & \\
\hline 8 B Compensa III & 127 & 4 & 1 & \\
\hline 9. Nova Esperança & - & 3 & - & \\
\hline 10. Lírio do Vale & 26 & - & - & \\
\hline 11. Conjunto Ajuricaba (Planalto) & 16 & 11 & 3 & \\
\hline 12. Alvorada I & 113 & 21 & 12 & \\
\hline 12 A Conj. Kissia I & - & 5 & 2 & \\
\hline 13. Redenção & 28 & 10 & 3 & 8 \\
\hline 14. Petrópolis & 95 & 4 & 1 & \\
\hline 15. Japiim & 27 & $\begin{array}{r}26 \\
1\end{array}$ & & \\
\hline 16. Coroado I & - & 2 & - & \\
\hline 16 A Coroado II & 10 & 2 & 2 & \\
\hline 16 B Coroado III & - & 9 & 13 & \\
\hline 17. Betânia & - & 5 & - & 5 \\
\hline 18. Conj. Dom Pedro II & - & 24 & 5 & \\
\hline 19. Conj. Eldorado & - & 5 & 1 & \\
\hline 20. Aleixo & 165 & 38 & 49 & 19 \\
\hline 21. Adrianópolis & 21 & 42 & 25 & 34 \\
\hline 22. Novo Israel & 56 & 6 & 7 & \\
\hline 23. Cidade Nova & 4 & 3 & - & 3 \\
\hline 24. São José & 26 & 6 & 5 & 4 \\
\hline 25. Tiradentes & - & 5 & 1 & 5 \\
\hline 26. Ouro Verde & 9 & 16 & 24 & 16 \\
\hline 27. João Paulo II & 21 & 2 & 1 & \\
\hline 28. Conjunto Vieira Alves & 27 & 2 & 1 & \\
\hline 29. Nova Jerusalém & 1 & - & - & \\
\hline 30. Unknown & - & 3 & 1 & \\
\hline Total & 1142 & 374 & 300 & \\
\hline
\end{tabular}


ing of dengue virus serotypes is recent and remains not widely used in epidemiological programs to identify the virus in mosquitoes. In the state of Rio de Janeiro it has been used to analyze Aedes mosquitoes for the presence of dengue viruses by RT-PCR and the results obtained, showed to be a good tool for monitoring dengue serotypes (Lourenço-de-Oliveira et al. 2002).

From 1998 to 2003, over 51 thousand cases of dengue fever and 114 of DHF were reported in Manaus. It is the single city in the Brazilian Amazon reporting a large number of severe dengue. The city of Belém, which is almost the same size as Manaus, has been also stricken by dengue epidemics involving the same serotypes since 1996 (Travassos da Rosa et al. 2000). Interesting, DHF/DSS cases were not recorded after over 84,608 reported dengue episodes (MS 2003). It is remarkable, however, that the three dengue serotypes circulating in Brazil had already been isolated in Manaus and Belém and significant differences were observed in the dengue occurrences on them (MS 2004).

The high infection rate detected in adult females suggests a large circulation of DENV3 in Manaus. On the other hand, all immatures specimens were negative by RT-PCR and virus isolation. This may be due to the small numbers of specimens collected during this study (Klin \& Klin 1983, Hull et al. 1984, Joshi et al. 1996).

The nucleotide sequence of the sample AR671089 was performed in order to confirm the RT-PCR results and determine the DENV3 circulating genotype. Following the alignment with sequences already recorded in the GENBANK, it was possible to determine its genetic characteristics. The DENV3 strain responsible for the epidemic in Manaus is closely related to the DENV3 genotype III, which corresponds to the Sri Lanka genotype originated in Asia (Fig. 3) (Lanciotti et al. 1994). Our results were similar to those published for the characterization of the first DENV3 isolate obtained in Brazil, in the state of Rio de Janeiro (Miagostovich et al. 2002), indicating that the virus genotype circulating in Manaus is similar to that in Rio de Janeiro (Fig. 3).

A striking finding that needs to be discussed here in is the reason why the DENV3 was the single serotype detected in our samples. We suppose that it is possible that DENV1 and DENV2 serotypes, that were responsible for the previous dengue epidemic episodes in Manaus, were displaced by DENV3, the last serotype introduced in Manaus. It is likely that part of the population had already been infected by the serotypes DENV1 and DENV2. However, the introduction of DENV3, found the whole population to be susceptible to it, which perhaps contributed to dispersion, thus becoming easier to be detected and isolated. In fact, earlier experiments showed that when a new dengue serotype is introduced into a community, occurs a natural decrease of circulation of other previously existing dengue serotypes (WHO 1997, Rigau-Pérez et al. 2002, Urdaneta et al. 2005). Moreover, the official data of the Ministry of Health, confirmed these findings, since only DENV3 isolations were officially recorded in 2003 (MS 2003).

The findings obtained in this study suggest that the Manaus population is under risk of suffering outbreaks of dengue that can be accompanied by an important occurrence of DHF cases, caused by the DENV3, as have been observed in other places (Gubler 1997, Guzman et al. 1998, Isturiz et al. 2000). The DENV3 was detected in several areas of the city where DHF cases were detected (Fig. 1). In the same year, 9 of 303 (3.1\%) samples collected from patients in Manaus were positive for DENV3 (Castro 2004). The law number reported may not show the real incidence of this virus type. This maybe due to sub notification of cases from the epidemiological surveillance.

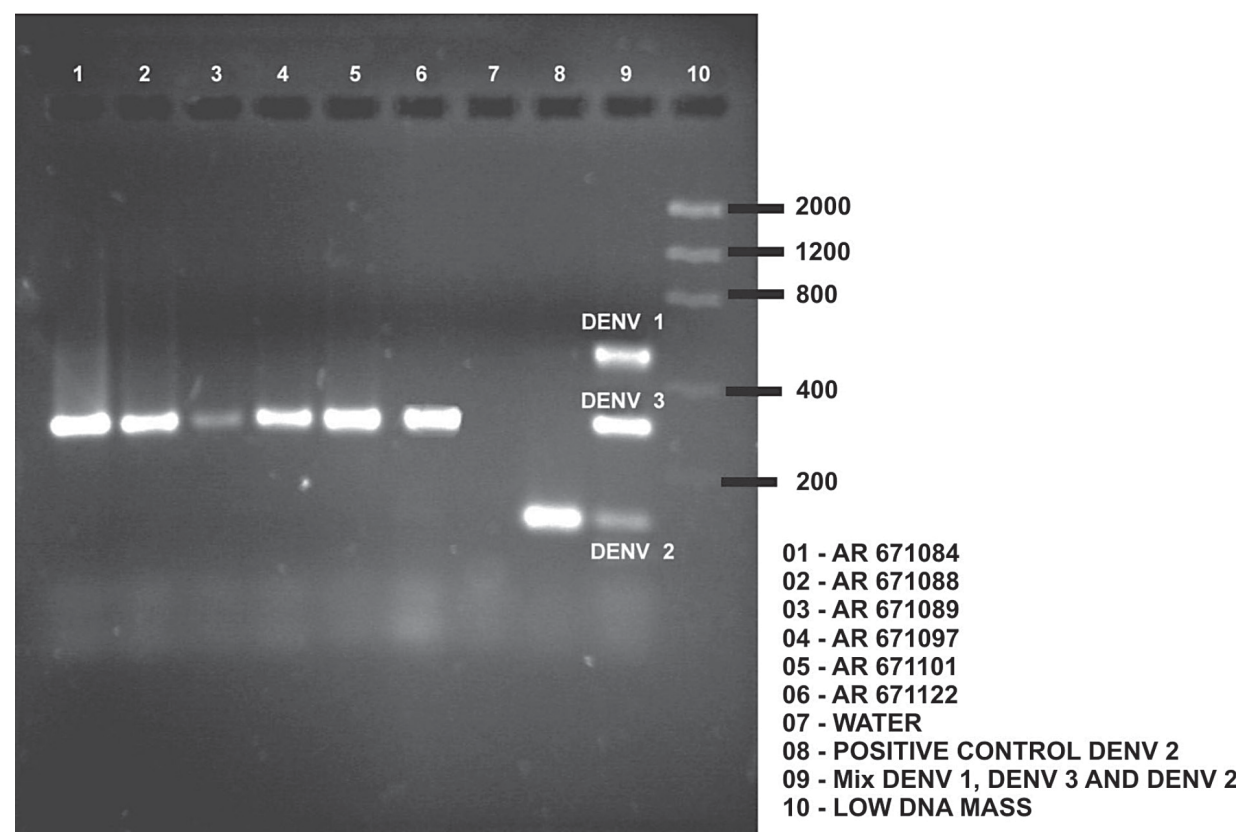

Fig. 2: reverse transcriptase-semi-nested-polymerase chain reaction (RT-PCR) product in $2 \%$ agarose gel stained with ethydium bromide. 


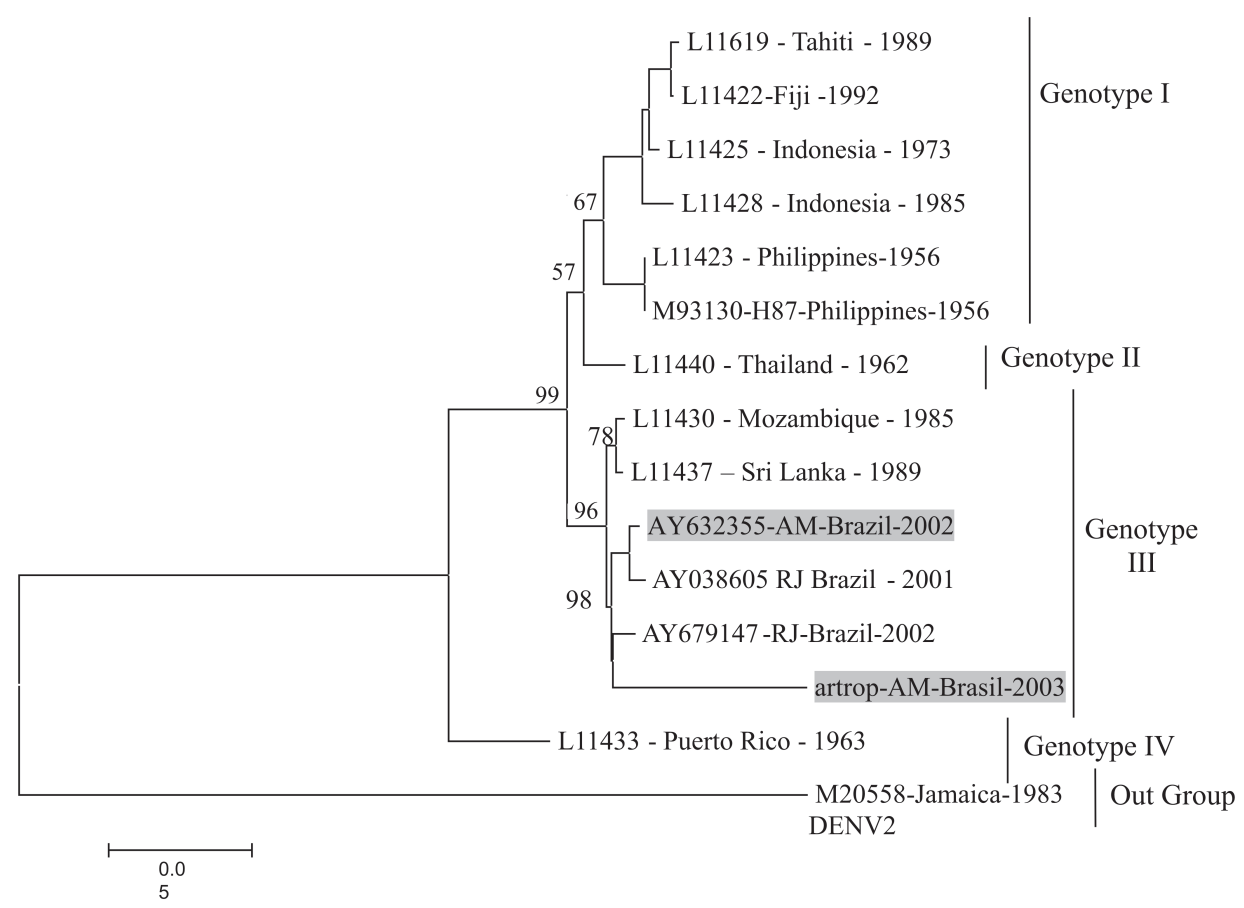

Fig. 3: philogenetic analyses of E gene seqüence to the DENV3. Comparison with 13 sequences representative to the genotypes I to IV obtained in Genbank. The analysis used the neighbor joing method; the nucleotide distance was calculated by kimura 2 parameters method. The values to the bootstrap were calculated after 1000 replicons and it was listed only main branches. The DENV2 sequence, acess number M20558, was used as outgroup. The DENV3 from Amazonas State is show in gray markers.

In Manaus, DENV3 was first detected in 2002 (Araújo et al. 2003). Thus, since the findings of that work there was an increased risk for the occurrence of DHF cases due to the high DENV3 circulation in the city and susceptible population for other serotypes in previous outbreaks (Siqueira Jr. et al. 2005). Perhaps, several other factors play a role for epidemic risks as well; the most important of them are the high Ae. aegypti indexes, and the lack of public health services, especially during the rainy season (December to June), when the clean rainy water promotes extensive breeding sites of Ae. aegypti, but also results in better geographical spread (Vasconcelos et al.1999, Pinheiro \& Tadei 2002).

On the other hand, the intensification of the vector control measures, the epidemiological surveillance, and the knowledge of the serotypes circulating in higher risk areas may prevent the occurrence of severe cases. Besides preventing the DENV3 dispersion in the population, the epidemiological surveillance must be able to monitor the circulation of other serotypes and also be able to early detect the introduction of the DENV4 that has been already isolated in Venezuela (Urdaneta et al. 2005), a bordering country with terrestrial connection to Manaus through a highway.

\section{REFERENCES}

Araújo GCA, Travassos da Rosa ES, Vasconcelos HB, Nunes MRT, Carvalho CLC, Rodrigues SG, Cruz ACR, Vasconcelos P 2003. Sorotipos de dengue isolados no Instituto Evandro Chagas no ano de 2002. Rev Soc Bras Med Trop 36(Supl. I): 16.
Braga IA, Lima JBP, Soares SS, Valle D 2004. Aedes aegypti resistance to temephos during 2001 in several municipalities in the states of Rio de Janeiro, Sergipe, and Alagoas, Brazil. Mem Inst Oswaldo Cruz 99: 199-203.

Castro JNC 2004. Aspectos Virológicos do Dengue no Estado do Amazonas, MSc Thesis, Universidade do Estado do Amazonas/Fundação de Medicina Tropical do Amazonas, Manaus, 63 pp.

Castro MG, Nogueira RMR, Schatzmayr HG, Miagostovich MP, Lourenço-de-Oliveira R 2004. Dengue vírus detection by using reverse transcription-polymerase chain reaction in saliva and progeny of experimentally infected Aedes albopictus from Brazil. Mem Inst Oswaldo Cruz 99: 809814.

Chow VT, Chan YC, Yong R, Lee KM, Lim LK, Chung YK, Lam-Phua SG, Tan BT 1998. Monitoring of dengue viruses in field-caught Aedes aegypti and Aedes albopictus mosquitoes by a type-specific polymerase chain reaction and cycle sequencing. Am J Trop Med Hyg 58: 578-586.

Chung YK, Pang FY 2002. Dengue virus infection rate in field populations of female Aedes aegypti and Aedes albopictus in Singapore. Trop Med Int Health 7: 322-330.

Chungue E, Roche C, Lefevre MF, Barbazan P, Chanteau S 1993. Ultra-rapid, simple, sensitive, and economical silica method for extraction of dengue viral RNA from clinical specimes and mosquitoes by reverse transcriptase-polymerase chain reaction. J Med Virol 40: 142-145.

Figueiredo LTM 2003. Dengue in Brazil: past, present and future perspective. Dengue Bull 27: 25-33. 
Figueiredo RMP, Bastus MS, Lima MJL, Almeida TMC, Alecrim WD 2002. Dinâmica da sorologia e isolamento viral na epidemia de dengue em Manaus (1998-2001). Rev Soc Bras Med Trop 35(Supl. I): 94.

Gubler DJ 1997. Dengue and dengue hemorrhagic fever: its history and resurgence as a global public health problem. In GE Kuno, Dengue and Dengue Hemorrhagic Fever, CAB International, New York, p.1-22.

Gubler DJ, Kuno GE, Sather GE, Valez M, Oliver A 1984. Mosquito cell cultures and monoclonal antibodies in survillance for dengue viruses. Am J Trop Med Hyg 33: 158-165.

Guzman M, Huelva G, Saenz E, Quiroz E, De los Reyes J, Balmaseda A 1998. Reintroduccion del dengue 3 en las Americas: 1994-1996. Arch Venez Med Trop 2: 8-19.

Halstead SB 1980. Dengue haemorrhagic fever, a public health problem and a field for research. Bull WHO 58: 1-21.

Harris E, Roberts TG, Smith L, Selle J, Kramer LD, Valle S, Sandoval S, Balmaseda A 1998. Typing of dengue viruses in clinical specimens and mosquitoes by single-tube multiplex reverse transciptase PCR. J Clin Microbiol 36: 2634-2639.

Hull B, Tikasingh E, de Souza M, Martinez R 1984. Natural transovarial transmission of dengue 4 virus in Aedes aegypti in Trinidad. Am J Trop Med Hyg 33: 1248-1250.

Isturiz RE, Gubler DJ, Brea del Castillo J 2000. Dengue and dengue hemorrhagic fever in Latin America and the Caribbean. Infect Dis Clin North Am 14: 121-140.

Joshi V, Mourya DT, Sharma RC. 2002. Persistence of dengue3 virus through transovarial transmission passage in sucessive generations of Aedes aegypti mosquitoes. Am J Trop Med Hyg 67: 158-161.

Joshi V, Singhi M, Chaudhary RC 1996. Transovarial transmission of dengue 3 by Aedes aegypti. Trans $R$ Soc Trop Med Hyg 90: 643-644.

Khin MM, Khin AT 1983. Transovarial transmission of dengue 2 virus by Aedes aegypti in nature. Am J Trop Med Hyg 32: 590-594.

Kouri G, Guzmán MG, Valdés L, Carbonell I, Rosario D, Vásquez S, Laferté J, Delgado J, Cabrera, MV 1998. Reemergence of dengue in Cuba: A 1997 epidemic in Santiago de Cuba. Emerg Infec Dis 4: 89-92.

Kow CY, Koon LL, Yin PF 2001. Detection of dengue viruses in field caught male Aedes aegypti and Aedes albopictus (Diptera: Culicidae) in Singapore by type-specific PCR. J Med Entomol 38: 475-479.

Lanciotti R, Calisher C, Gubler D, Chang G, Vorndam V 1992. Rapid detection and typing of dengue viruses from clinical samples by using reverse transcriptase-polymerase chain reaction. J Clin Microbiol 30: 545-551.

Lanciotti RS, Lewis JG, Gubler DJ, Trent DW 1994. Molecular evolution and epidemiology of dengue viruses. J Gen Virol 75: 65-75.

Lourenço-de-Oliveira R, Honorio NA, Castro MG, Schatzmayr HG, Miagostovich MP, Alves JCR, Silva WC, Leite PJ, Nogueira RMR 2002. Dengue virus type 3 isolation from Aedes aegypti in the municipality of Nova Iguaçu, state of Rio de Janeiro. Mem Inst Oswaldo Cruz 97: 799-800.
Messer WB, Gubler DJ, Harris E, Sivananthan K, de Silva AM 2003. Emergence and global spread of a dengue serotype 3, subtype III virus. Emerg Infect Dis 9: 800-809.

Miagostovich MP, Santos FB, Simone, TS, Costa EV, Fillippis AMB, Schatzmayr HG, Nogueira RMR 2002. Genetic characterization of dengue virus type 3 isolates in the State of Rio de Janeiro, 2001. Braz J Med Biol Res 35: 869-872.

MS-Ministério da Saúde. 2003. Secretaria de Vigilância em Saúde. Dengue - Boletim da semana 44/2003, Brasília 11 pp.

MS-Ministério da Saúde 2004. Secretaria de Vigilância em Saúde. Relatório técnico - 2004.

MS-Ministério da Saúde 2005. Secretaria de Vigilância em Saúde. Dengue - Boletim da semana 04/2005, Brasília 13 pp.

Nogueira RMR, Schatzmayr HG, Miagostovich MP, Farias MFDB, Farias Filho JC 1988. Virological study of dengue type 1 epidemic in Rio de Janeiro, Brazil. Mem Inst Oswaldo Cruz 83: 219-225.

Pinheiro VCS, Tadei WP 2002. Frequency, diversity, and productivity study on the Aedes aegypti most preferred containers in the city of Manaus, Amazonas, Brazil. Rev Inst Med Trop São Paulo 44: 245-250.

Reynes JM 1995. Tentatives d'Isolement d'Arbovirus a Partir de Serum ou Surnageants de Moustiques sur Cellules APG1, Inst Pasteur, Guyane.

Rigau-Pérez JG, Ayala-López A, Gargía-Rivera EJ, Hudson SM, Vorndam V, Reiter P, Cano MP, Clark GG 2002. The reappearance of dengue- 3 and a subsequent dengue- 4 and dengue-1 epidemic in Puerto Rico in 1998. Am J Trop Med Hyg 67: 355-362.

Romero-Vivas CME, Sutherland CJ, Falconar AKI 2000. The use of direct sequencing of dengue virus cDNA from individual field-collected Aedes aegypti for surveillance and epidemiological studies. J Med Entomol 14: 89-94.

Sinan-Sistema de Informação de Agravos de Notificaçoes 2004. Available: http://www.saude.am.gov.br/saude/compulsorias.php. Acess in 2004.

Siqueira Jr. JB, Martelli CMT, Coelho GE, Simplício ACR, Hatch DL 2005. Dengue and dengue hemorrhagic fever, Brazil, 1981-2002. Emerg Infect Dis 11: 48-53.

Travassos da Rosa APA, Vasconcelos PFC, Travassos da Rosa ES, Rodrigues SG, Mondet B, Cruz ACR, Sousa MR, Travassos da Rosa JFS 2000. Dengue epidemic in Belém, Pará, Brazil, 1996-97. Emerg Infect Dis 6: 298-299.

Urdaneta L, Herrera F, Pernalete M, Zoghbi N, Rubio-Palis Y, Barrios R, Rivero J, Comach G, Jimenez M, Salcedo M 2005. Detection of dengue viruses in field-caught Aedes aegypti (Diptera: Culicidae) in Maracay, Aragua state, Venezuela by type-specific polymerase chain reaction. Infect Genet Evol 5: 177-184.

Vasconcelos PFC, Lima JWO, Travassos da Rosa APA, Timbó MJ, Travassos da Rosa ES, Lima HR, Rodrigues SG, Travassos da Rosa JFS 1998. Epidemia de dengue em Fortaleza, Ceará: inquérito soro-epidemiológico aleatório. Rev Saúde Públ 32: 447-454.

Vasconcelos PFC, Travassos da Rosa APA, Pinheiro FP, Rodrigues SG, Travassos da Rosa ES, Cruz ACR, Travassos 
da Rosa JFS 1999. Aedes aegypti, dengue and re-urbanization of yellow fever in Brazil and other South American Countries. Past and present, and future perspectives. WHO Dengue Bulletin 23: 55-66.

Vaughn DW, Green S, Kalayanarooj S, Innis BL, Nimmannitya S, Suntayakorn S, Endy TP, Raengsakulrach B, Rothman
AL, Ennis FA, Nisalak A 2000. Dengue viremia titer, antibody response pattern, and virus serotype correlate with disease severity. J Infect Dis 181: 2-9.

WHO-World Health Organization 1997. Dengue Haemorrhagic Fever: Diagnosis, Treatment and Control, 2nd ed., Geneva, $84 \mathrm{pp}$. 